\title{
Serum copper and erythrocyte superoxide dismutase in rheumatoid arthritis
}

\author{
J. C. BANFORD, D. H. B ROWN, R. A. HAZELTON, C. J. MCNEIL, \\ R. D. STURROCK, AND W. E. SMITH \\ From the Department of Pure and Applied Chemistry, University of Strathclyde, and the Centre for Rheumatic \\ Disease, Baird Street, Glasgow
}

SUMMARY Serum copper and thiol levels and caeruloplasmin activity were determined and compared with measurements of articular index, erythrocyte sedimentation rate, and zinc and haemoglobin levels in patients with rheumatoid arthritis. Superoxide dismutase activity, thiol, zinc, and copper levels of haemolysate were measured and compared with each other and to the above parameters. In serum, caeruloplasmin activity increased and thiol levels decreased, whereas in the haemolysate, superoxide dismutase activity decreased and thiol levels increased. It is suggested that the changes in copper levels and in the activities of processes which may be copper-dependent between plasma and cytosol in patients with rheumatoid arthritis reflect a change in oxidative status of the blood which may have implications in the pathogenesis of the disease.

The role of copper in inflammatory processes has recently been of interest, particularly because of the abnormally high serum copper levels ${ }^{12}$ and synovial fluid copper levels ${ }^{3}$ found in patients with rheumatoid arthritis. Furthermore, a potentially greater anti-inflammatory activity of copper complexes of anti-inflammatory agents as compared with the agents themselves has been observed in animal models of inflammation. ${ }^{4}$ This work has been extended to show that some copper compounds of nonactive ligands have a significant antiinflammatory effect when administered either orally or subcutaneously. ${ }^{5}$

Copper ions react with biological materials, and almost all body copper is complexed in some form. Most plasma copper is accounted for by caeruloplas$\min (\sim 90 \%)$, with smaller amounts of copper present bound to albumin and amino acids. However, the distribution of copper within the cell is less well defined. Superoxide dismutase is known to account for about $40 \%$ of the copper in haemolysate, but the other $60 \%$ is variously stated as being due to another protein or to small copper molecules. ${ }^{6}$

Copper appears to play an important part as the active site of a number of key enzymes involved in oxidation-reduction processes. Caeruloplasmin has several important functions related to its oxidase

Accepted for publication 24 August 1981.

Correspondence to Dr W. E. Smith, Department of Pure and Applied Chemistry, University of Strathclyde, Thomas Graham Building, 295 Cathedral Street, Glasgow G1 1XL. activity. ${ }^{7}$ For example, it is a specific substrate for the oxidation of cysteine to cystine. ${ }^{8}$ Superoxide dismutase, the main copper-containing enzyme in the cytosol of both leucocytes and erythrocytes, is believed to control the effect of the potentially toxic superoxide anion produced by the reduction of oxygen. ${ }^{9}$ At present there is considerable uncertainty about the relationship between superoxide dismutase activity and inflammatory disease. For example, in one study of superoxide dismutase in polymorphonuclear leucocytes of patients with juvenile rheumatoid arthritis ${ }^{10}$ a significant reduction in activity compared with the norm is reported, and in another study the activity in a haemolysate was not significantly reduced. ${ }^{11}$ In this paper we have correlated copper-related parameters with other measures of disease activity such as articular index, erythrocyte sedimentation rate (ESR), and haemoglobin and suggest that they reflect a systemic change in the degree of oxidation between intra- and extracellular fluids. Since superoxide dismutase also contains zinc, and since zinc and copper levels have often been compared in disease processes, we have also measured zinc concentration in serum and haemolysate.

\section{Patients and methods}

The patients examined were all suffering from classical or definite rheumatoid arthritis as defined by the criteria of the American Rheumatism Association. ${ }^{12}$ 
The groups studied were 49 controls ( 22 male, 27 female) and 85 patients ( 22 male, 63 female). The age range of the control group was from 20 to 61 years and of the patients from 25 to 60 . A small group of 5 female controls on oestrogen-based oral contraceptives were also included. No patients included in the study were receiving any form of hormone treatment or were using oral contraceptives. Fiftyfive patients were receiving 2 nd-line medication (gold 29, penicillamine 14, and levamisole 12), and the remainder were receiving various nonsteroidal anti-inflammatory agents alone. The parameters were correlated by linear regression, and the significance of differences between groups was obtained by Student's $t$ test. Copper was estimated by atomic absorption spectrophotometry using carbon furnace atomisation ${ }^{13}$ and zinc by flame atomic fluorescence. $^{14}$ Caeruloplasmin oxidase activity was measured by the method of Menden et al. ${ }^{15}$ and caeruloplasmin concentration by immunoassay. ${ }^{16}$ Oxidase activities were recalculated in terms of protein concentration by a factor derived from measurements on a standard sample of human caeruloplasmin (Hoechst); both oxidase and immunoassay methods were used. Thiol levels were estimated by Ellman's method. ${ }^{17}$ Superoxide dismutase activity was obtained by measuring the rate of photo-oxidation of $o$-dianisidine sensitised by riboflavin..$^{18}$ The erythrocyte sedimentation rate, haemoglobin levels, and articular index were measured by standard techniques. Heparinised blood samples were separated by centrifugation $(4000 \mathrm{rpm}$ for 10 minutes) in a Mistral $6 \mathrm{~L}$ centrifuge. The plasma was removed, the cells were washed with isotonic saline solution, and cell lysis was carried out by adding an equal volume of distilled water. After 2 hours' lysis at $4^{\circ} \mathrm{C}, 2 \mathrm{ml}$ of haemolysate was removed and to it was added $0.8 \mathrm{ml}$ of a mixture of chloroform and ethanol $(3: 5 \mathrm{v} / \mathrm{v})$ at $0^{\circ} \mathrm{C}$ to precipitate the haemoglobin, followed by $0.3 \mathrm{ml}$ of distilled water. The mixture was then centrifuged, and the resulting clear supernatant was used directly for the estimation of superoxide dismutase activity and thiol concentration. Thiol levels fall gradually with time; therefore all thiol estimations were carried out between 12 and 24 hours after sampling.

Pellicon membranes with a molecular weight cutoff of about 1000 were used for ultrafiltration.

\section{Results}

Serum copper levels were raised and serum thiol levels were reduced in this study (Table 1), in agreement with most previous findings. Caeruloplasmin was measured in 2 different ways, and, when the oxidase activity was converted to concentration and compared with the immunoassay, there was a close correlation $(r=0.805, p<0 \cdot 001)$. This correlation was reflected in both control and patient groups. Therefore the activity per molecule did not change in the disease state but the amount of caeruloplasmin present did.

There was a good correlation between serum copper and serum thiol levels in patients with rheumatoid arthritis, (Table 2). The link between these 2 parameters is complex as is indicated by the results for the 5 normal persons taking oestrogenbased contraceptives, for whom a copper level in excess of that for rheumatoid patients was measured but for whom there was only a small decrease in thiol concentration (Table 1). Total serum copper correlated well with disease indices such as articular index and ESR and to a less extent with haemoglobin and serum zinc levels. However, correlations with serum

Table 2 Statistical correlations between serum copper and other clinical parameters in $R A$ patients

\begin{tabular}{lllll}
\hline & $\begin{array}{l}\text { Articular } \\
\text { index }\end{array}$ & ESR & $\begin{array}{l}\text { Rheumatoid } \\
\text { factor } \\
\text { titre }\end{array}$ & \\
\hline Serum copper & $\mathrm{n}=84$ & $\mathrm{n}=84$ & $\mathrm{n}=76$ & \\
& $\mathrm{r}=0.478$ & $\mathrm{r}=0.470$ & $\mathrm{r}=0.258$ & \\
$\mathrm{p}<0.001$ & $\mathrm{p}<0.001$ & $\mathrm{p}<0.05$ & \\
& $\begin{array}{l}\text { Serum } \\
\text { thiol }\end{array}$ & $\begin{array}{l}\text { Serum } \\
\text { iron }\end{array}$ & $\begin{array}{l}\text { Serum } \\
\text { zinc }\end{array}$ & $\begin{array}{l}\text { Haemo- } \\
\text { globin }\end{array}$ \\
& $\mathrm{n}=84$ & $\mathrm{n}=200$ & $\mathrm{n}=77$ & $\mathrm{n}=85$ \\
$\mathrm{r}=-0.669$ & $\mathrm{r}=-0.275$ & $\mathrm{r}=-0.369$ & $\mathrm{r}=-0.365$ \\
$\mathrm{p}<0.01$ & $\mathrm{p}<0.001$ & $\mathrm{p}<0.001$ \\
\hline Serum copper & $\mathrm{p}<0.001$ & $\mathrm{p}<0.01$ & & \\
& & & &
\end{tabular}

Table 1 A comparison of serum copper, ultrafilterable copper, caeruloplasmin oxidase activity, and caeruloplasmin concentration by immunoassay between patients with rheumatoid arthritis and controls. Normal females taking oestrogen are shown separately. No patients were using hormones

\begin{tabular}{|c|c|c|c|c|c|c|}
\hline Group & $n$ & $\begin{array}{l}\text { Serum } \\
\text { copper } \\
\text { umol/l-1 }\end{array}$ & $\begin{array}{l}\text { Ultrafilterable } \\
\text { copper } \\
\text { umol/l }\end{array}$ & $\begin{array}{l}\text { Caeruloplasmin } \\
\text { oxidase activity } \\
(\mathrm{mg} / 100 \mathrm{ml})\end{array}$ & $\begin{array}{l}\text { Caeruloplasmin } \\
\text { concentration } \\
(\mathrm{mg} / 100 \mathrm{ml})\end{array}$ & $\begin{array}{l}\text { Serum } \\
\text { SH } \\
\left(\mu \mathrm{mol} / l^{-1}\right)\end{array}$ \\
\hline $\begin{array}{l}\text { Normal } \\
\text { RA } \\
\text { Females on oestrogen }\end{array}$ & $\begin{array}{r}49 \\
85 \\
5\end{array}$ & $\begin{array}{l}14 \cdot 95 \pm 0 \cdot 55 \\
26 \cdot 28 \pm 5 \cdot 66 \\
28 \cdot 32 \pm 5 \cdot 18\end{array}$ & $\begin{array}{l}1 \cdot 13 \pm 0 \cdot 55 \\
1 \cdot 23 \pm 0 \cdot 71 \\
-\end{array}$ & $\begin{array}{l}34 \cdot 0 \pm 6 \cdot 0 \\
52 \cdot 8 \pm 7 \cdot 5 \\
65 \cdot 1 \pm 7 \cdot 4\end{array}$ & $\begin{array}{l}32 \cdot 5 \pm 6 \cdot 3 \\
53 \cdot 0 \pm 10 \cdot 7 \\
65 \cdot 2 \pm 9 \cdot 1\end{array}$ & $\begin{array}{l}537 \pm 85 \\
368 \pm 93 \\
486 \pm 26\end{array}$ \\
\hline
\end{tabular}

Activities converted to concentrations for comparison. SI conversion: caeruloplasmin oxidase activity and concentration $\mathrm{mg} / \mathrm{l}=\mathrm{mg} / 100 \mathrm{ml} \times 10$. 
iron and rheumatoid factor titre were only slightly significant (Table 2). The correlation between total serum copper and ESR or articular index suggested that copper levels could be used as another measure of disease severity.

Therefore the patient group was divided into mild, moderate, and severe categories on the basis of copper levels (Table 3 ). On the basis of 6 copper atoms per caeruloplasmin molecule the percentage of serum copper present as caeruloplasmin was calculated. There was a clear decrease with increasing disease severity, indicating that another form of copper was present in the serum of patients with rheumatoid arthritis and that the amount was linked to the activity of the disease. There appeared to be an increase in ultrafilterable copper with increasing copper level, but the amount was not large enough to account for the additional copper.

There was no significant difference in either the copper or zinc level in haemolysate between patients and controls, although the haemoglobin level dropped as expected (Table 4). Free thiol measurements were taken after precipitation of haemoglobin and must be regarded as 'residual thiol' concentrations following probable oxidation of the nonhaemoglobin thiol during separation. They indicate a higher level for nonhaemoglobin thiol in the diseased than in the normal state. Superoxide dismutase activity (SOD) was significantly decreased.

There was no correlation between the total copper level in the cytosol and superoxide dismutase activity for either controls (Table 5) or patients (Table 6). For normal persons the only strong correlations noted were between the residual thiol and zinc concentrations. In the patient group the correlation between thiol concentration and superoxide dismutase activity was strong, but there was no significant correlation between thiol and zinc concentrations. Copper and zinc levels within the cell did not correlate with clinical indices, but residual thiol concentration and superoxide dismutase activity were significantly correlated with them. Superoxide dismutase activity, in particular, would appear to be an indicator of disease response (Table 6).

\section{Discussion}

Although caeruloplasmin has been examined in numerous chemical and biochemical studies, considerable doubt still remains as to the copper content

Table 4 A comparison of results from lysed cells of normal persons and $R A$ patients

\begin{tabular}{|c|c|c|}
\hline & Normals & $R A$ patients \\
\hline Copper $\left.(\mu \mathrm{g} \mathrm{ml})^{-1}\right)$ & $0 \cdot 74 \pm 0 \cdot 13$ & $0.69 \pm 0.26$ \\
\hline Zinc $\left(\mu \mathrm{g} \mathrm{ml}^{-1}\right)$ & $12 \cdot 1 \pm 1 \cdot 6$ & $12 \cdot 1 \pm 2 \cdot 1$ \\
\hline $\begin{array}{l}\text { Superoxide dismutase } \\
\text { activity }\left(\mu \mathrm{g} \mathrm{ml}^{-1}\right)\end{array}$ & $104 \cdot 1 \pm 12 \cdot 9$ & $81 \cdot 4 \pm 17 \cdot 7$ \\
\hline Thiol $\left(\mu \mathrm{mol} \mathrm{1}{ }^{-1}\right)$ & $111 \pm 72$ & $194 \pm 131$ \\
\hline Haemoglobin (g/dl) & $14 \cdot 4 \pm 1 \cdot 2$ & $11 \cdot 7 \pm 1 \cdot 6$ \\
\hline Red blood cells $\left(\times 10^{12} 1^{-1}\right)$ & $4 \cdot 77 \pm 0 \cdot 44$ & $4 \cdot 3 \pm 0 \cdot 6$ \\
\hline ESR & - & $44 \pm 32$ \\
\hline Articular index & - & $8 \cdot 7 \pm 7 \cdot 1$ \\
\hline
\end{tabular}

Table 5 Statistical correlations for control group

\begin{tabular}{llll}
\hline & Zinc & SOD & Thiol \\
\hline Copper & $\mathrm{n}=23$ & $\mathrm{n}=23$ & $\mathrm{n}=17$ \\
& $\mathrm{r}=-0.25$ & $\mathrm{r}=0.21$ & $\mathrm{r}=0.006$ \\
& $\mathrm{NS}$ & $\mathrm{NS}$ & $\mathrm{NS}$ \\
Zinc & & $\mathrm{n}=23$ & $\mathrm{n}=17$ \\
& & $\mathrm{r}=-0.164$ & $\mathrm{r}=-0.663$ \\
SOD & $\mathrm{NS}$ & $\mathrm{p}<0.005$ \\
& & & $\mathrm{n}=17$ \\
& & $\mathrm{r}=-0.728$ \\
& & $\mathrm{p}<0.001$ \\
\hline
\end{tabular}

SOD=superoxide dismutase. $\mathrm{NS}=$ not significant.

Table 3 Serum copper distribution in patients with rheumatoid arthritis selected on a basis of disease activity as reflected by total serum copper compared with control groups

\begin{tabular}{|c|c|c|c|c|c|c|}
\hline Group & $n$ & $\begin{array}{l}\text { Serum } \\
\text { copper } \\
\text { emol 1 }^{-1}\end{array}$ & $\begin{array}{l}\text { Serum } \\
\text { caerulo- } \\
\text { plasmin } \\
(\mathrm{mg} / 100 \mathrm{ml})\end{array}$ & $\begin{array}{l}\text { Caerulo- } \\
\text { plasmin } \\
\text { copper } \$ \\
(\text { umol l-1) }\end{array}$ & $\begin{array}{l}\text { Cp copper } \\
\text { Serum } \\
\text { copper }\end{array}$ & $\begin{array}{l}\text { Serum } \\
\text { ultrafiltrate } \\
\text { copper } \\
\left(\text { pmol } l^{-1}\right)\end{array}$ \\
\hline Normal & 49 & $15 \cdot 00 \pm 2 \cdot 0$ & $32 \cdot 5 \pm 6 \cdot 3$ & $14 \cdot 3 \pm 2 \cdot 8$ & 96 & $\begin{array}{l}1 \cdot 13 \pm 0 \cdot 55 \\
(\mathrm{n}=22)\end{array}$ \\
\hline $\begin{array}{l}\text { Females taking } \\
\text { oestrogen }\end{array}$ & 5 & $28 \cdot 3 \pm 5 \cdot 2$ & $65 \cdot 2 \pm 9 \cdot 1$ & $28 \cdot 7 \pm 4 \cdot 04$ & 101 & - \\
\hline Mild RA* & 28 & $19 \cdot 0 \pm 2 \cdot 0$ & $42 \cdot 0 \pm 6 \cdot 5$ & $18 \cdot 5 \pm 2 \cdot 9$ & 97 & $\begin{array}{l}0 \cdot 87 \pm 0 \cdot 47 \\
(n=15)\end{array}$ \\
\hline Moderate RA† & 40 & $25 \cdot 3 \pm 1 \cdot 7$ & $53 \cdot 5 \pm 10 \cdot 3$ & $23 \cdot 6 \pm 4 \cdot 5$ & 93 & $\begin{array}{l}1 \cdot 23 \pm 0.72 \\
(\mathrm{n}=20)\end{array}$ \\
\hline Severe RA & 27 & $31 \cdot 00 \pm 5 \cdot 2$ & $61 \cdot 9 \pm 14 \cdot 9$ & $27 \cdot 3 \pm 6 \cdot 6$ & 86 & $\begin{array}{l}1 \cdot 57 \pm 0.79 \\
(n=19)\end{array}$ \\
\hline
\end{tabular}

"Serum copper less than $22.03 \mu \mathrm{mol} \mathrm{1^{-1 }}$.

tSerum copper between 22.03 and $28 \cdot 33 \mu \mathrm{mol}^{-1}$.

$\ddagger$ Serum copper greater than $28 \cdot 33 \mu \mathrm{mol} \mathrm{1}^{-1}$.

$\$$ Calculated assuming 6 copper atoms per caeruloplasmin molecule.

SI conversion: serum caeruloplasmin $\mathrm{mg} / \mathrm{l}=\mathrm{mg} / 100 \mathrm{ml} \times 10$. 
Table 6 Statistical correlations for rheumatoid arthritis group

\begin{tabular}{|c|c|c|c|c|c|c|c|c|}
\hline & $C u$ & $Z n$ & $S O D$ & Thiol & $E S R$ & $H b$ & $R B C$ & $A I$ \\
\hline $\mathrm{Cu}$ & & $\begin{array}{l}n=33 \\
r=-0.443 \\
p<0.01\end{array}$ & $\begin{array}{l}\mathrm{n}=34 \\
\mathrm{r}=-0 \cdot 257 \\
\mathrm{NS}\end{array}$ & $\begin{array}{l}n=28 \\
r=-0 \cdot 228 \\
\text { NS }\end{array}$ & $\begin{array}{l}n=34 \\
r=0 \cdot 054 \\
N S\end{array}$ & $\begin{array}{l}n=46 \\
r=-0 \cdot 224 \\
\text { NS }\end{array}$ & $\begin{array}{l}n=34 \\
r=0 \cdot 016 \\
N S\end{array}$ & $\begin{array}{l}n=34 \\
r=0.08 \\
\text { NS }\end{array}$ \\
\hline $\mathrm{Zn}$ & & & $\begin{array}{l}n=45 \\
r=-0 \cdot 102 \\
\text { NS }\end{array}$ & $\begin{array}{l}n=38 \\
r=0.061 \\
\text { NS }\end{array}$ & $\begin{array}{l}n=45 \\
r=0.04 \\
\text { NS }\end{array}$ & $\begin{array}{l}n=45 \\
r=0.015 \\
\text { NS }\end{array}$ & $\begin{array}{l}n=45 \\
n=0 \cdot 13 \\
\text { NS }\end{array}$ & $\begin{array}{l}n=45 \\
r=0 \cdot 101 \\
N S\end{array}$ \\
\hline SOD & & & & $\begin{array}{l}n=39 \\
r=-0.798 \\
p<0.001\end{array}$ & $\begin{array}{l}n=46 \\
r=-0.286 \\
p 0 \cdot 05\end{array}$ & $\begin{array}{l}n=46 \\
r=0.41 \\
p 0 \cdot 005\end{array}$ & $\begin{array}{l}n=46 \\
r=0.352 \\
p 0.05\end{array}$ & $\begin{array}{l}n=46 \\
r=-0 \cdot 46 \\
p 0 \cdot 002\end{array}$ \\
\hline Thiol & & & & & $\begin{array}{l}n=39 \\
r=0 \cdot 291 \\
N S\end{array}$ & $\begin{array}{l}n=39 \\
r=-0.38 \\
p 0 \cdot 02\end{array}$ & $\begin{array}{l}\mathrm{n}=39 \\
\mathrm{r}=-0.35 \\
\mathrm{p} 0.05\end{array}$ & $\begin{array}{l}n=39 \\
r=-0.437 \\
p 0.01\end{array}$ \\
\hline ESR & & & & & & $\begin{array}{l}n=46 \\
r=-0.61 \\
p<0.001\end{array}$ & $\begin{array}{l}n=46 \\
r=-0 \cdot 69 \\
p 0 \cdot 001\end{array}$ & $\begin{array}{l}n=46 \\
r=0.805 \\
p 0 \cdot 001\end{array}$ \\
\hline $\mathrm{Hb}$ & & & & & & & $\begin{array}{l}n=46 \\
r=0.685 \\
p<0.001\end{array}$ & $\begin{array}{l}n=46 \\
r=-0.51 \\
p 0.001\end{array}$ \\
\hline RBC & & & & & & & & $\begin{array}{l}n=46 \\
r=-0.354 \\
p<0.02\end{array}$ \\
\hline
\end{tabular}

SOD = superoxide dismutase. $\mathrm{NS}=$ not significart.

of the protein-probably because of its susceptibility to proteolytic cleavage. ${ }^{19}$ Recent measurements of molecular weight and copper content are consistent with 6 or 7 copper atoms per molecule,$^{20}$ and loss of one copper atom can be effected without alteration of spectral or catalytic properties. ${ }^{21}$ As yet, however, there is no in-vivo evidence to suggest the existence of caeruloplasmin molecules with different copper contents, and there is also no change in activity per molecule (Table 1) in this study. Therefore on the basis of 6 copper atoms per caeruloplasmin molecule the percentage of serum copper which is not present as an integral part of the caeruloplasmin molecule, although it could be carried by it, is reduced in the disease state. The reduction is not due to a concomitant rise in ultrafilterable copper and would appear to indicate that a new form of copper is present in the serum. This could be extra copper carried by a protein, as is the case where orally absorbed copper has an anti-inflammatory effect, ${ }^{5}$ or it could be a copper polypeptide, as postulated on the basis of urinary copper studies. ${ }^{22}$ In any event an increase in the amount of this new form of copper or of total serum copper appears to indicate an increase in disease activity.

Patients with rheumatoid arthritis have low zinc and high copper concentration in serum as compared with normal subjects. However, within cells it would appear (Table 4) that there is no similar perturbation. Further, there is a correlation between zinc and thiol levels in normal subjects, but this correlation is lacking in the disease state, where there is a variation in intracellular thiols. Most zinc is present within the cell as carbonic anhydrase, and it would seem that the zinc balance is controlled in spite of the fluctuation in related systems caused by the disease.

Previous studies of superoxide dismutase activity in rheumatoid disease have yielded apparently conflicting results, although different clinical types of inflammatory joint disease and different cell populations were studied. ${ }^{10}{ }^{11}$ In the present study superoxide dismutase activity in general reflects the severity of the disease as measured by articular index and ESR, whereas erythrocyte copper does not (Table 6). There was a significant lowering of superoxide dismutase activity, with no concomitant lowering of erythrocyte copper levels (Table 6). An attempt at altering superoxide dismutase levels in arthritic patients has been made by using parenteral injections of a bovine dismutase (Orgotein) ${ }^{23}$ which appears to have a short-lived anti-inflammatory effect. However, the effects of added Orgotein on intracellular superoxide dismutase activity are not known.

The correlation between haemolysate thiol concentration and superoxide dismutase activity in both patients and controls is very significant, of a comparable degree to that between caeruloplasmin concentration and activity. The residual thiol must be a result of extensive thiol oxidation on cell lysis and haemoglobin precipitation. Initially intracellular glutathione concentrations are of the order of $2 \mathrm{mmol}^{-1}$. ${ }^{24}$ Thus the lower superoxide dismutase activity, the lower the thiol oxidation. It is possible that, superimposed on normal air oxidation of glutathione, the reduction 


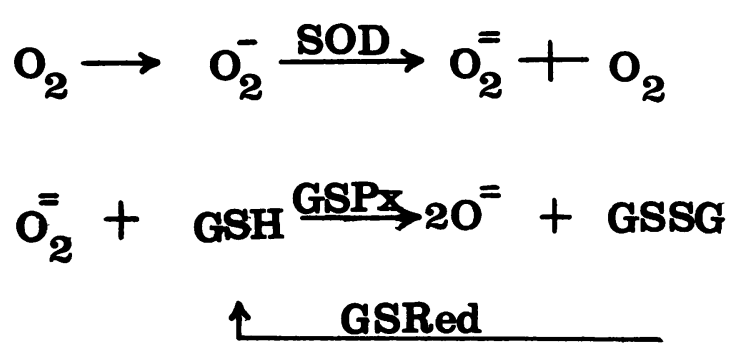

Fig. 1 A possible relationship between the reduction of oxygen and glutathione (GSH) involving the enzymes superoxide dismutase (SOD) glutathione peroxidase $(G S P x)$ and glutathione reductase (GSRed). GSSG = diglutathione.

products of oxygen react with glutathione according to the reactions set out in Fig. 1.

On the assumption that, following cell lysis, the glutathione reductase reaction is stopped because its energy arises from the membrane-based NADP ${ }^{+}$ $\rightleftharpoons$ NADPH reaction, then the lower the superoxide dismutase activity the less peroxide produced, and hence less glutathione oxidised, that is, a higher residual thiol will be found. The reaction is likely to be more complicated than the above, but it may illustrate a type of reaction that could contribute to the results obtained.

From a clinical viewpoint the pattern of concentrations and activities of enzymes containing a large fraction of blood copper changes in a manner characteristic of the disease state. Whether it is uniquely characteristic will require further studies of other disease groups, but the results for normal females taking oestrogens indicate that a different pattern of results is possible. One common feature of these enzymes is their likely role in oxygen metabolism and in oxidation processes, and it may be that the change in copper status reflects the oxygen deficiency believed to occur in affected joints, which gives rise to an increased lactic acid production and decreased $\mathrm{pH}^{25}$

In any event, taken in conjunction with the thiol status, these levels suggest that the serum is more oxidised (more disulphide) and the cytosol more reduced (more sulphydryl groups). Such changes would affect many aspects of enzyme release, cell life time, iron mobilisation, etc, and could account for or be a reflection of the severity of the biochemical aspect of rheumatoid arthritis.

\section{References}

${ }^{1}$ Scudder P R, Al-Timini D, McMurray W, White A G, Zoob B C, Dormandy $T$ L. Serum copper and related variables in rheumatoid arthritis. Ann Rheum Dis 1978; 37: 67-70.
${ }^{2}$ Brown D H, Buchanan W W, El-Ghobarey A, Smith W E, Teape J. Serum copper and its relationship to clinical symptoms in rheumatoid arthritis. Ann Rheum Dis 1979; 38: 174-6.

${ }^{3}$ Scudder P R, McMurray W, White A G, Dormandy T L. Synovial fluid copper and related variables in rheumatoid arthritis and degenerative arthritis, Ann Rheum Dis 1978; 37: 71-2.

4 Sorenson J R J. Copper chelates as possible active forms of the anti-arthritic agents. J Med Chem 1976; 19: 135-48.

5 Brown D H, Lewis A J, Smith W E, Teape J. The antiinflammatory effects of some copper complexes. J Med Chem 1980; 23: 729-32.

- Reed D W, Passon P E, Hultquist D E. Purification and properties of a pink copper protein from human erythrocytes. J Biol Chem 1970; 245: 2954-61.

7 Gutteridge J M C. Caeruloplasmin: a plasma protein, enzyme and antioxidant. Ann Clin Biochem 1978; 15: 293-6.

8 Albergoni V, Cassini A. The oxidation of cysteine by caeruloplasmin. FEBS Lett 1975; 55: 261-4.

9 Concetti A, Massei P, Rotilio G, Brunori M, Rachmilewitz E A. Superoxide dismutase in red blood cells: method of assay and enzyme content in subjects and in patients with $\beta$-thalassemia (major and intermedia), J Lab Clin Med 1976; 87: 1057-64.

10 Rister M, Bauermeister K, Gravert U, Gladtke E. Superoxide dismutase deficiency in rheumatoid arthritis. Lancet 1978; i: 1094.

${ }^{11}$ Scudder P R, Stocks J, Dormandy T L. The relationship between superoxide dismutase activity and erythrocyte copper levels in normal subjects and in patients with rheumatoid arthritis. Clin Chim Acta 1976; 69: 397-403.

12 Ropes H W, Bennett G A, Cobb S, Jacob R, Tesser R. Diagnostic criteria for rheumatoid arthritis. Ann Rheum Dis 1959; 18: 49-53.

${ }^{13}$ Kamel H, Teape J, Brown D H, Smith W E, Ottaway J M. Determination of copper in plasma ultrafiltrates by atomic absorption spectrometry using a carbon furnace. Analyst 1978; 103: 921-7.

14 Michel R G, Hall M L, Ottaway J M, Fell G S. Determination of cadmium in blood and urine by flame atomic fluorescence spectrometry. Analyst 1979; 104: 491-504.

15 Menden E E, Boiano J M, Murthy L, Petering H G. Modifications of a p-PD oxidase method to permit non-automated caeruloplasmin determinations in batches of rat serum or plasma microsamples. Anal Lett 1977; 10: 197-204.

${ }^{16}$ Mancini G, Carbonara A O, Heremans J F. Immunochemical quantitation of antigens by single radial diffusion. Immunochemistry 1965; 2: 235-8.

${ }^{17}$ Ellman G L. Tissue sulphydryl groups. Arch Biochem Biophys 1959; 82: 70-7.

${ }^{18}$ Misra H P, Fridovich I. Superoxide dimutase: a photochemical augmentation assay. Arch Biochem Biophys 1977; 181: 308-12.

19 Kingston I B, Kingston B L, Putnam F W. Chemical evidence that proteolytic cleavage causes the heterogeneity present in human caeruloplasmin preparations. Proc Natl Acad Sci USA 1977; 74: 5377-81.

${ }^{20}$ Ryden L, Bjork I. Reinvestigation of some physiochemical and chemical properties of human caeruloplasmin. Biochemistry 1976; 15: 3411-7.

${ }^{21}$ Huber CT, Frieden E. Substrate activation and kinetics of ferroxidase. J Biol Chem 1970; 245: 3973-8.

${ }^{22}$ McMurray W, Martin V M, Sucdder P, Stocks J, White A G, Dormandy $\mathrm{T} \mathrm{L}$. Urinary copper excretion in rheumatoid arthritis. Ann Rheum Dis 1975; 34: 340-5.

${ }^{23}$ Martelli E A. Orgotein-a review. Med Actual 1980; 16: 97-101.

24 Hagenfeldt L, Arvidsson A, Larsson A. Glutathione and $\gamma$ glutamylcysteine in whole blood, plasma and erythrocytes. Clin Chim Acta 1978; 85: 167-73.

${ }^{25}$ Goetzl E J, Falchiek K H, Zeiger L S, et al. A physiological approach to the assessment of disease activity in rheumatoid arthritis. J Clin Invest 1971; 50: 1167-80. 